\title{
Dopamine Agonists: From the 1970s to Today
}

\author{
Renata S. Auriemma Rosa Pirchio Dario De Alcubierre Rosario Pivonello Annamaria Colao \\ Dipartimento di Medicina Clinica e Chirurgia, Federico II University, Naples, Italy
}

\author{
Keywords \\ Hyperprolactinemia - Pituitary tumor · Dopamine agonists . \\ Bromocriptine - Cabergoline - Lisuride · Pergolide . \\ Quinagolide
}

\begin{abstract}
The discovery of dopamine inhibitory effects on prolactin secretion has led to an era of successful dopaminergic therapy for prolactinomas. Herein we provide an overview of the evolution of dopamine agonists and their use in patients with PRL-secreting pituitary tumors, starting from the 1970 s up to today, highlighting that normalization of PRL levels, restoration of eugonadism, and reduction of tumor mass can be achieved in the majority of patients by treatment with dopamine agonists.

(c) 2019 S. Karger AG, Basel

\section{Introduction}

Indications for therapy in patients with prolactinomas include effects of tumor size and effects of hyperprolactinemia $[1,2]$. Whereas in asymptomatic patients with microprolactinomas there is no absolute requirement for treatment $[1,2]$ as a significant growth of these tumors is quite uncommon [3], symptoms of hyperprolactinemia in patients harboring a microadenoma or a macroadeno-
\end{abstract}

\section{KARGER}

๑ 2019 S. Karger AG, Basel

E-Mail karger@karger.com

www.karger.com/nen ma encourage the starting of prolactin (PRL)-lowering treatment $[1,2]$. The presence of a macroadenoma raises the probability that tumor may have propensity to grow [1]. Moreover, most macroprolactinomas are associated with remarkable PRL elevations so that to elicit symptoms that would require treatment. Therefore, unless specifically contraindicated, therapy is usually advisable for these tumors [1,2]. Tumor invasiveness and compression of adjacent structures, such as the stalk or optic chiasm, are additional indications for therapy $[1,2]$. Other indications are directly ascribable to the hyperprolactinemia itself, and include decreased libido, menstrual dysfunction, galactorrhea, infertility, hirsutism, impotence, and premature osteoporosis $[1,2]$. According to international guidelines [2], dopamine agonist therapy is the recommended treatment to lower PRL levels, decrease tumor size, and restore gonadal function in patients harboring symptomatic PRL-secreting microadenomas or macroadenomas $[1,4]$. The compounds most commonly used in clinical practice to treat prolactinomas are bromocriptine and cabergoline, whereas pergolide, quinagolide, and lisuride are less frequently used or not available anymore [1]. Bromocriptine, pergolide, and cabergoline are all ergot derivatives, whereas quinagolide is the only nonergot derivative used in clinical practice. Prolactinomas can exhibit variable responsiveness to medical therapy, and resistance to dopamine agonists, defined as failure to achieve normoprolactinemia and at least a $30 \%$
Prof. Annamaria Colao, $\mathrm{MD}, \mathrm{PhD}$

Dipartimento di Medicina Clinica e Chirurgia, Sezione di Endocrinologia Federico II University, Via Sergio Pansini 5

IT-80131 Naples (Italy)

E-Mailcolao@unina.it 
Table 1. Effects of bromocriptine on PRL normalization and tumor shrinkage

\begin{tabular}{|c|c|c|c|c|c|}
\hline Study & $\begin{array}{l}\text { Patients, } \\
n\end{array}$ & Dose, mg/day & $\begin{array}{l}\text { PRL normaliza- } \\
\text { tion cases, } n\end{array}$ & $\begin{array}{l}\text { Eugonadism }{ }^{\text {a }} \\
\text { cases, } n\end{array}$ & $\begin{array}{l}\text { Tumor shrinkage }{ }^{b} \text {, } \\
\text { cases }\end{array}$ \\
\hline Seppälä et al. [20] & 14 & 5 & 12 & 8 & - \\
\hline Carter et al. [21] & 22 & - & 7 & 9 & - \\
\hline Thorner et al. [26] & 12 & $2.5-7.5$ & 12 & 12 & - \\
\hline Beckers et al. [28] & 29 & 50-150 (LAR) & 28 & 8 & 14 \\
\hline Merola et al. [29] & 22 & $2.5-15$ & 15 & 13 & 10 \\
\hline Total & 99 & - & $74(74.7 \%)$ & $50(50.5 \%)$ & $24(47 \%)^{\mathrm{c}}$ \\
\hline
\end{tabular}

\footnotetext{
${ }^{a}$ Defined as restoration of regular menstrual cycles, pregnancy, and/or a normal libido or potency. ${ }^{\mathrm{b}}$ Defined as a reduction $>25 \%$ of the baseline volume. ${ }^{c}$ Calculated based on 51 patients with available data about pituitary imaging.
}

reduction in tumor size, is reported in up to $30 \%$ of patients treated with bromocriptine and in approximately $10 \%$ of those receiving cabergoline $[5,6]$. Treatment approaches for patients resistant to dopamine agonists include a switch to an alternative dopamine agonist, drug escalation beyond conventional doses, surgical tumor resection, radiotherapy, and temozolomide for aggressive or malignant tumors $[2,5,6]$.

\section{Ergot-Mediated Inhibition of Prolactin Secretion}

At the beginning of 1970s, administration of the PRL inhibitor 2-bromo-a-ergokryptine to lactating cows was shown to display, besides a remarkable reduction in serum PRL levels, only a small effect on the milk yield [7]. However, treatment immediately before parturition effectively inhibited the onset of lactation [8]. In female rats 1-h treatment with the ergot alkaloids ergocornine and ergocristine at $0.25-1 \mathrm{mg}$ was shown to induce persistent PRL decrease [9]. Both compounds were found to block the proestrus surge of PRL levels as well as the PRL increase induced by estradiol benzoate at 5-50 $\mu \mathrm{g}$ in oophorectomized rats [9], whereas high-dose ergocornine ( $2 \mathrm{mg}$ ) induced abrupt cessation of lactation with a concomitant fall in PRL levels. These findings led to the conclusion that ergot alkaloids had an intense inhibitory effect on PRL secretion and might be used in medical therapeutics. Moreover, increasing evidence ruled out the capability of some ergot alkaloids or their derivatives, such as ergometrine, agroclavine, or 2-bromo-a-ergocryptine (bromocriptine), to act as potential dopamine-mimetic drugs [10-13], therefore raising the question of whether these compounds might be used in clinical settings, mainly for pa- tients with Parkinson's disease [14] or hyperprolactinemia [15] whose symptoms have been demonstrated to be relieved by dopamine-mimetic drugs. Particularly, agents able for stimulate $\alpha$-adrenergic or dopaminergic receptors were found to inhibit PRL release [16]. The evidence that hypothalamic catecholamines, including dopamine, can directly inhibit in vitro PRL secretion supported the hypothesis that dopamine physiologically inhibits PRL secretion by stimulating specific receptors at the pituitary level [16]. Similarly, in cultured pituitary cells maintained in serum-free medium, dopamine and the dopamine agonist bromocriptine were demonstrated to inhibit PRL synthesis and PRL mRNA levels [17], suggesting that this might be useful for therapeutic application [17].

\section{Bromocriptine}

The greatest experience with dopamine agonists has been gained with the semisynthetic ergot alkaloid bromocriptine, which was specifically developed to inhibit PRL secretion, with low oxytocic and cardiovascular effects compared to other ergot alkaloids. The therapeutic effects of bromocriptine on PRL levels, restoration of eugonadism, and tumor shrinkage are shown in Table 1. In patients suffering from hyperprolactinemia-hypogonadism syndrome bromocriptine, administered at a dose of $2.5 \mathrm{mg}$ 2 or 3 times/day, allowed the resumption of menstruation in hypogonadal women and immediately improved symptoms which, however, returned upon cessation of the drug [18]. In women and men receiving treatment with bromocriptine, PRL levels normalized and galactorrhea improved in the first few weeks of therapy [19], cyclical ovarian function resumed within 6 weeks to 9 months [19], and 
Table 2. Effects of pergolide on PRL normalization and tumor shrinkage

\begin{tabular}{|c|c|c|c|c|c|}
\hline Study & $\begin{array}{l}\text { Patients, } \\
n\end{array}$ & Dose, $\mu \mathrm{g} /$ day & $\begin{array}{l}\text { PRL normaliza- } \\
\text { tion cases, } n\end{array}$ & $\begin{array}{l}\text { Eugonadism }^{\text {a }} \\
\text { cases, } n\end{array}$ & $\begin{array}{l}\text { Tumor shrinkage } \\
\text { cases, } n\end{array}$ \\
\hline Kleinberg et al. [36] & 41 & $50-350$ & 37 & 27 & 15 \\
\hline Orrego et al. [37] & 22 & $50-500$ & 15 & 5 & 19 \\
\hline Total & 63 & - & $52(82.5 \%)$ & $32(50.8 \%)$ & $34(54 \%)$ \\
\hline
\end{tabular}

testosterone levels increased in approximately $70 \%$ of the patients [20]. Similar results were seen in 32 patients with secondary amenorrhea (14 patients with PRL levels from 32 to $620 \mathrm{ng} / \mathrm{mL}$ ) receiving bromocriptine $2.5 \mathrm{mg}$ twice daily [21], with approximately $78 \%$ of patients achieving PRL normalization. In cultures of human pituitary tumors [22] bromocriptine was demonstrated to inhibit acutely PRL secretion by $64.4 \pm 2.7 \%$ and after a 3 -day therapy by $76.9 \pm 3-8 \%$ [22]. When administered in patients with PRL-secreting pituitary tumors, a significant reduction of tumor mass or complete tumor regression were reported [23-25]. Moreover, spontaneous pregnancies were found to occur in women treated for infertility with bromocriptine. No evidence of teratogencity associated with bromocriptine was highlighted; nevertheless, women should have been recommended to stop treatment as soon as pregnancy was suspected [26, 27].

Side effects of bromocriptine included postural hypotension, nausea, and vomiting [16] and were avoided by slow initiation of the therapy [16].

Therefore, at the beginning of the 1990s bromocriptine was recommended as the standard medical treatment for prolactinomas, as it could induce inhibition of PRL synthesis and secretion at the pituitary level as well as tumor shrinkage $[28,29]$. Nevertheless, some studies performed in the 1980s [30-33] documented a resistance to bromocriptine in $9-46 \%$ of patients, raising the question of whether other dopamine agonists might be useful to treat hyperprolactinemia when bromocriptine has failed to allow disease control.

\section{Pergolide}

Pergolide mesylate, a synthetic ergot derivative that shares similar pharmacologic properties with bromocriptine but has a longer duration of activity, was shown to induce a dose-dependent and prolonged decrease in or suppression of PRL levels in 4 healthy volunteers [34], allowing disease control with only 1 daily dose with greater patient compliance [35]. At higher doses, uncomfortable symptoms, including nausea, emesis, postural lightheadedness, emotional lability, mood changes, tremor, headache, and nasal stuffiness, were reported $[34,35]$. In a study on 41 patients with hyperprolactinemia treated for 19-31 months with pergolide at 25-1,600 $\mu \mathrm{g}$ /day, PRL levels normalized in $90 \%$ and the tumor mass shrank in $77 \%$ of patients [36]. In women, gonadal function was restored in two thirds of the cases, with $76 \%$ of the patients achieving regular menses and $24 \%$ achieving pregnancy [36]. Similarly, male patients experienced testosterone normalization in 58\%, increased libido in 59\%, and increased potency in $35 \%$ of the cases [36]. Treatment was generally well tolerated, and therapy discontinuation was required only in 3 patients because of nausea and vomiting [36]. When used as the primary treatment in $22 \mathrm{pa}-$ tients with macroprolactinomas for 3-36 months at a dose of $0.1-0.75 \mathrm{mg} /$ day, PRL normalization and tumor shrinkage (at least 25\%) were found to occur in 68.2 and $86.4 \%$ of the cases, respectively [37]. The therapeutic effects of pergolide on PRL levels, restoration of eugonadism, and tumor shrinkage are shown in Table 2.

However, the enthusiasm for the use of pergolide ended at the beginning of the 2000s due to the finding of restrictive valvular heart disease in $33 \%$ of patients with Parkinson's disease who had received pergolide but in none of those who had never been treated with this drug [38]. A few years later, the increased risk of newly diagnosed moderate to severe valvular regurgitation was confirmed in patients with Parkinson's disease treated with pergolide or cabergoline as compared to those receiving different anti-Parkinsonian medications [39, 40], with the risk of valvular disease being significantly related to cumulative dose and treatment duration.
36

Neuroendocrinology 2019;109:34-41 DOI: $10.1159 / 000499470$
Auriemma/Pirchio/De Alcubierre/ Pivonello/Colao 
Table 3. Effects of quinagolide on PRL normalization and tumor shrinkage

\begin{tabular}{|c|c|c|c|c|c|}
\hline Study & $\begin{array}{l}\text { Pat } \\
n\end{array}$ & , Dose, $\mu \mathrm{g} / \mathrm{day}$ & $\begin{array}{l}\text { PRL normaliza- } \\
\text { tion cases, } n\end{array}$ & $\begin{array}{l}\text { Eugonadism }{ }^{\text {a }} \\
\text { cases, } n\end{array}$ & $\begin{array}{l}\text { Tumor shrinkage } \\
\text { cases }^{\text {b }}, n\end{array}$ \\
\hline van der Lely et al. [49] & 20 & $25-300$ & 13 & 13 & 20 \\
\hline Brue et al. [50] & 21 & $25-500$ & 10 & 5 & 11 \\
\hline Merola et al. [51] & 40 & $75-600$ & 31 & 31 & 24 \\
\hline Total & 81 & - & $54(66.7 \%)$ & $49(60.5 \%)$ & $55(67.9 \%)$ \\
\hline
\end{tabular}

Consequently, in 2007 pergolide was withdrawn from US market [41].

\section{Lisuride}

Lisuride hydrogen maleate is an isoergolene derivative with strong peripheral anti-serotoninergic and central dopaminergic activity which is able to inhibit PRL secretion [42, 43]. Given orally or subcutaneously, lisuride was found to be very effective in lowering serum PRL concentrations in both intact reserpinized and ovariectomized rats primed with estradiol benzoate, with or without additional pretreatment with reserpine [43]. In 11 women with hyperprolactinemia and secondary amenorrhea, long-term treatment (7-18 weeks) with lisuride at 50-200 $\mu \mathrm{g} /$ day induced PRL normalization in $81.8 \%$, regular menses resumption in $81.8 \%$, and ovulation restoration in $72.7 \%$ of the cases [44]. In 53 women receiving lisuride at $300 \mu \mathrm{g}(n=26)$ or $600 \mu \mathrm{g}(n=27)$ daily, lactation was effectively inhibited and PRL levels suppressed in a doserelated manner [45]. Nausea and drowsiness were the most commonly reported side effects of lisuride $[45,46]$.

\section{Quinagolide}

Quinagolide is the most active nonergot oral medication that also functions as a dopamine agonist with specific D2 receptor activity, and it is about 35 times more potent than bromocriptine. In normal rat and tumoral human pituitary cells, low doses of quinagolide were demonstrated to induce immediate and sustained PRL suppression [47]. These effects were more potent and longer acting than the previously described in vitro effects of bromocriptine. In 7 patients resistant to bromocriptine

Dopamine Agonists: From the 1970s to

Today up to $15 \mathrm{mg}$ daily, a 6-month treatment with quinagolide at $75-800 \mu \mathrm{g}$ /day induced a PRL decrease in $42.8 \%$ and PRL normalization in $28.6 \%$ of the cases, albeit with no relevant change in tumor size [48]. One woman became pregnant during quinagolide treatment [48]. In 3 independent studies [49-51] (Table 3) including overall 81 patients with prolactinomas resistant to bromocriptine, a 6- to 12 -month treatment with quinagolide at variable daily doses induced PRL normalization in $66.7 \%$ of the cases and tumor shrinkage in $68 \%$ of the patients; libido/ potency increased in $86 \%$ of the men and regular menses were restored in $67 \%$ of the women [49]. These findings suggested that at least half of patients resistant to bromocriptine quinagolide can overcome such a resistance probably due to its higher affinity toward the D2 dopamine receptor [50]. In general, the tolerability was high, and only in a few cases were nausea, vomiting, and postural hypotension reported [51].

\section{Cabergoline}

Cabergoline was first synthesized by scientists working for an Italian drug company who were experimenting with semisynthetic derivatives of the ergot alkaloids. In cultured pituitary cells from estradiol-induced rat pituitary tumors, a significant PRL inhibition was found within $12 \mathrm{~h}$ after treatment with cabergoline $[52,53]$. Continued oral administration of cabergoline significantly reduced both PRL levels and pituitary weight during 15-60 days of treatment as compared with bromocriptine [52]. In healthy male volunteers, a single cabergoline administration $(0.2-0.6 \mathrm{mg})$ induced a dose-dependent PRL inhibition [54]. In healthy men, single doses of $0.5,1$, and $1.5 \mathrm{mg}$ of cabergoline induced complete PRL suppression [55], whereas in healthy women with regular menses dos- 
Table 4. Effects of cabergoline on PRL normalization and tumor shrinkage

\begin{tabular}{|c|c|c|c|c|c|}
\hline Study & $\begin{array}{l}\text { Patients, } \\
n\end{array}$ & Dose, mg/week & $\begin{array}{l}\text { PRL normaliza- } \\
\text { tion cases, } n\end{array}$ & $\begin{array}{l}\text { Eugonadism }{ }^{\mathrm{a}} \\
\text { cases, } n\end{array}$ & $\begin{array}{l}\text { Tumor shrinkage } \\
\text { cases, } n\end{array}$ \\
\hline Wenster et al. [58] & 223 & $0.25-2$ & 186 & 201 & - \\
\hline Colao et al. [59] & 23 & $0.5-3$ & 19 & 21 & 14 \\
\hline Colao et al. [60] & 110 & $0.25-3.5$ & 88 & 94 & 93 \\
\hline Total & 356 & - & $293(82.3 \%)$ & $316(88.8 \%)$ & $107(80.4 \%)^{\mathrm{c}}$ \\
\hline
\end{tabular}

es of 0.4-0.6 mg induced 43-76\% PRL suppression [56], with PRL remaining suppressed until 5 days after the administration of $0.6 \mathrm{mg}$ [56]. In 31 hyperprolactinemic patients randomized to cabergoline at 0.3 or $0.6 \mathrm{mg}$ once weekly for 9 weeks, PRL normalization occurred in $74.2 \%$ of the patients and regular menses resumption was seen in 15 out of 17 premenopausal women with amenorrhea [57]. The tolerability to cabergoline was very high, and nausea, vomiting, arterial hypotension, and dizziness were reported only by a few patients [57]. In a large patient series including 459 hyperprolactinemic women randomly assigned to cabergoline at $0.5-1.0 \mathrm{mg} /$ week or to bromociptine $2.5-5.0 \mathrm{mg}$ twice daily, PRL normalization was achieved in $83 \%$ of patients treated with cabergoline $(92 \%$ of patients with idiopathic hyperprolactinemia or microprolactinoma and $77 \%$ of patients with macroprolactinoma) as compared to $59 \%$ of those receiving bromocriptine [58], and ovulatory cycles or spontaneous pregnancies were seen in 72 and $52 \%$ of patients treated with cabergoline and bromocriptine, respectively [58]. Side effects were less frequent and less severe in women treated with cabergoline as compared to bromocriptine [58], suggesting that cabergoline was more effective and better tolerated as compared to bromocriptine [58]. Remarkable tumor shrinkage ( $>20 \%$ of the baseline tumor size) was observed in more than $80 \%$ of the patients after 12-24 months of therapy with cabergoline, with complete disappearance of the tumor mass in 26$36 \%$ of the cases [59]. Moreover, cabergoline treatment was seen to induce further tumor shrinkage in $60 \%$ of patients previously treated with other dopamine agonists as compared to $82.3 \%$ of previously untreated patients [60]. The therapeutic effects of cabergoline on PRL levels, restoration of eugonadism, and tumor shrinkage are shown in Table 4.
Nowadays, according to the last international guidelines [2] cabergoline is recommended as the treatment of choice for patients with prolactinomas because of its greater efficacy over bromocriptine and other dopamine agonists in inducing PRL normalization and a clinically relevant ( $\geq 50 \%$ of baseline size) reduction in tumor volume $[1,2,61]$.

\section{Resistance to Dopamine Agonists}

Despite the remarkable efficacy in lowering of PRL levels and tumor mass shrinkage, patients with prolactinomas may develop a resistance to dopamine agonists. This condition of resistance has not merited a unique definition in the literature, and different hypotheses, including failure to normalize or to reduce PRL levels sufficiently to achieve ovulation, failure to induce a $50 \%$ reduction of hyperprolactinemia, and/or failure to reduce tumor size [1], have been proposed. On the other hand, there is no standard dose threshold for dopamine agonists above which a patient may be considered resistant to dopamine agonists [5]. Actually, resistance to dopamine agonists is defined as a failure to achieve normoprolactinemia and at least a 30\% reduction in tumor size [6]. Several molecular mechanisms, including decreased medication absorption, a decreased number of $\mathrm{D} 2$ receptors on the resistant tumors, a decreased affinity of the D2 receptors for the dopamine agonists, and altered signal transduction, have been proposed as being responsible for resistance to dopamine agonists [1,62]. More recently, sequence variants of some genes, including the proline-rich salivary protein PRB3 [63] and the retinoblastoma interacting zinc finger protein PRDM2 [64], as well as alterations in the TGF- $\beta$ / Smad signaling pathway [65], have been reported as pos-
38

Neuroendocrinology 2019;109:34-41 DOI: $10.1159 / 000499470$
Auriemma/Pirchio/De Alcubierre/ Pivonello/Colao 
sible mechanisms of tumor resistance or recurrence for prolactinomas. Genetic predisposition has been also investigated as a potential factor underlying resistance to dopamine agonists. Mutations in MEN1 and AIP genes have been found to be associated with a larger tumor size, aggressive clinical behavior, and reduced responsiveness to dopamine agonists in patients with prolactinomas [6668]. Clinical predictive factors of resistance to medical treatment with dopamine agonists include male gender [68-70], a young age $[71,72]$, large $[68,70]$ or cystic $[71$, 72] tumors, and tumor invasiveness [68, 70]. Resistance to dopamine agonists may be defeated by drug escalation beyond conventional doses, surgical tumor resection, radiotherapy, and temozolomide for aggressive or malignant tumors $[2,5,6]$.

\section{Conclusions}

The introduction of dopamine agonists in the therapeutic algorithm for prolactinomas completely changed the natural history of these tumors over last 50 years, offering an effective treatment strategy that progressively replaced surgery and radiotherapy in the routine clinical management of such tumors. Dopamine agonist therapy, mainly cabergoline, is nowadays recommended as the treatment of choice to lower PRL levels, decrease the tumor size, and restore gonadal function in patients harboring PRL-secreting microadenomas or macroadenomas. Nevertheless, multimodal therapy involving also surgery and/or radiotherapy may be necessary in patients resistant to the effects of dopamine agonists or for those with aggressive prolactinomas.

\section{References}

1 Gillam MP, Molitch ME, Lombardi G, Colao A. Advances in the treatment of prolactinomas. Endocr Rev. 2006 Aug;27(5):485-534.

2 Melmed S, Casanueva FF, Hoffman AR, Kleinberg DL, Montori VM, Schlechte JA, et al.; Endocrine Society. Diagnosis and treatment of hyperprolactinemia: an Endocrine Society clinical practice guideline. J Clin Endocrinol Metab. 2011 Feb;96(2):273-88.

3 Schlechte J, Dolan K, Sherman B, Chapler F, Luciano A. The natural history of untreated hyperprolactinemia: a prospective analysis. J Clin Endocrinol Metab. 1989 Feb;68(2):412-8.

4 Colao A, Lombardi G. Growth-hormone and prolactin excess. Lancet. 1998 Oct;352(9138): 1455-61.

5 Auriemma RS, Grasso LF, Pivonello R, Colao A. The safety of treatments for prolactinomas. Expert Opin Drug Saf. 2016;15(4):503-12.

6 Maiter D. Management of dopamine agonistresistant prolactinoma. Neuroendocrinology. DOI: 10.1159/000495775.

7 Karg H, Schams D, Reinhardt V. Effects of 2-Br- -ergocryptine on plasma prolactin level and milk yield in cows. Experientia. 1972 May;28(5):574-6.

8 Schams D, Reinhardt V, Karg H. Effects of 2-Br--ergokryptine on plasma prolactin level during parturition and onset of lactation in cows. Experientia. 1972 Jun;28(6):697-9.

9 Nasr H, Pearson OH. Inhibition of prolactin secretion by ergot alkaloids. Acta Endocrinol (Copenh). 1975 Nov;80(3):429-43.

10 Fuxe K, Corrodi H, Hökfelt T, Lidbrink P, Ungerstedt U. Ergocornine and 2-Br-alphaergocryptine. Evidence for prolonged dopamine receptor stimulation. Med Biol. 1974 Apr;52(2):121-32.

11 Stone TW. Further evidence for a dopamine receptor stimulating action of an ergot alkaloid. Brain Res. 1974 May;72(1):177-80.
12 Woodruff GN, Elkhawad AO, Crossman AR. Further evidence for the stimulation of rat brain dopamine receptors by ergometrine. J Pharm Pharmacol. 1974 Jun;26(6):455-6.

13 Schorderet M. Direct evidence for the stimulation of rabbit retina dopamine receptors by ergot alkaloids. Neurosci Lett. 1976 Apr;2(2): 87-91.

14 Hornykiewicz O. Parkinson's disease and its chemotherapy. Biochem Pharmacol. 1975 May;24(10):1061-5.

15 Thorner MO. Dopamine is an important neurotransmitter in the autonomic nervous system. Lancet. 1975 Mar; 1(7908): 662-5.

16 MacLeod RM, Lehmeyer JE. Studies on the mechanism of the dopamine-mediated inhibition of prolactin secretion. Endocrinology. 1974 Apr;94(4):1077-85.

17 Maurer RA. Dopaminergic inhibition of prolactin synthesis and prolactin messenger RNA accumulation in cultured pituitary cells. J Biol Chem. 1980 Sep;255(17):8092-7.

18 Besser GM, Thorner MO. Bromocriptine in the treatment of the hyperprolactinaemia-hypogonadism syndromes. Postgrad Med J. 1976;52(52 suppl 1):64-70.

19 Thorner MO. Disorders of prolactin secretion. J Clin Pathol. 1976;30:36-41.

20 Seppălă M, Hibroven E, Ranta T, Virkkunen P, Leppăluoto J. Raised serum prolactin levels in amenorrhoea. BMJ. 1975 May;2(5966): 305-6.

21 Carter JN, Tyson JE, Tolis G, Van Vliet S, Faiman C, Friesen HG. Prolactin-screening tumors and hypogonadism in $22 \mathrm{men}$. N Engl J Med. 1978 Oct;299(16):847-52.
22 Mashiter K, Adams E, Beard M, Holley A. Bromocriptine inhibits prolactin and growthhormone release by human pituitary tumours in culture. Lancet. 1977 Jul;2(8030): 197-8.

23 Landolt AM. Progress in pituitary adenoma biology - results of research and clinical applications. In: Krayenbühl $\mathrm{H}$, et al., editors. Advances and technical standards in neurosurgery. Vienna: Springer; 1978. pp. 3-49.

24 Sobrinho LG, Nunes MC, Santos MA, Mauricio JC. Radiological evidence for regression of prolactinoma after treatment with bromocriptine. Lancet. 1978 Jul;2(8083):257-8.

25 Landolt AM, Wüthrich R, Fellmann H. Regression of pituitary prolactinoma after treatment with bromocriptine. Lancet. 1979 May; 1(8125):1082-3.

26 Thorner MO, Besser GM, Jones A, Dacie J, Jones AE. Bromocriptine treatment of female infertility: report of 13 pregnancies. BMJ. 1975 Dec;4(5998):694-7.

27 Thorner MO, Besser GM. Hyperprolactinaemia and gonadal function: results of bromocriptine treatment. In: Crosignani PG, Robyn C: Prolactin and human reproduction: proceedings of the Serono Symposium. London: Academic Press; 1977.

28 Beckers A, Petrossians P, Abs R, Flandroy P, Stadnik T, de Longueville $\mathrm{M}$, et al. Treatment of macroprolactinomas with the long-acting and repeatable form of bromocriptine: a report on 29 cases. J Clin Endocrinol Metab. 1992 Jul;75(1):275-80.

29 Merola B, Colao A, Caruso E, Sarnacchiaro F, Lancranjan I, Lombardi G, et al. Effectiveness and long-term tolerability of the slow release oral form of bromocriptine on tumoral and non-tumoral hyperprolactinemia. J Endocrinol Invest. 1992 Mar;15(3):173-6. 
30 Grisoli F, Vincentelli F, Jaquet P, Guibout M, Hassoun J, Farnarier P. Prolactin secreting adenoma in 22 men. Surg Neurol. 1980 Apr; 13(4):241-7.

31 Grossman A, Wass JA, Besser M. The rapid diagnosis of sensitivity or resistance to dopamine agonists with depot bromocriptine. Acta Endocrinol (Copenh). 1987 Oct;116(2): 275-81.

32 Pellegrini I, Rasolonjanahary R, Gunz G, Bertrand $\mathrm{P}$, Delivet $\mathrm{S}$, Jedynak CP, et al. Resistance to bromocriptine in prolactinomas. J Clin Endocrinol Metab. 1989 Sep;69(3): 500-9.

33 Brue T, Pellegrini I, Priou A, Morange I, Jaquet $P$. Prolactinomas and resistance to dopamine agonists. Horm Res. 1992;38(1-2):84-9.

34 Lemberger L, Crabtree R, Callaghan JT. Pergolide, a potent long-acting dopamine-receptor agonist. Clin Pharmacol Ther. 1980 May; 27(5):642-51.

35 Franks S, Horrocks PM, Lynch SS, Butt WR London DR. Treatment of hyperprolactinaemia with pergolide mesylate: acute effects and preliminary evaluation of longterm treatment. Lancet. 1981 Sep;2(8248): 659-61.

36 Kleinberg DL, Boyd AE 3rd, Wardlaw S, Frantz AG, George A, Bryan N, et al. Pergolide for the treatment of pituitary tumors secreting prolactin or growth hormone. N Engl J Med. 1983 Sep;309(12):704-9.

37 Orrego JJ, Chandler WF, Barkan AL. Pergolide as primary therapy for macroprolactinomas. Pituitary. 2000 Dec;3(4):251-6.

38 Van Camp G, Flamez A, Cosyns B, Weytjens C, Muyldermans L, Van Zandijcke M, et al. Treatment of Parkinson's disease with pergolide and relation to restrictive valvular heart disease. Lancet. 2004 Apr;363(9416): 1179-83.

39 Schade R, Andersohn F, Suissa S, Haverkamp W, Garbe E. Dopamine agonists and the risk of cardiac-valve regurgitation. $\mathrm{N}$ Engl J Med. 2007 Jan;356(1):29-38.

40 Zanettini R, Antonini A, Gatto G, Gentile R, Tesei S, Pezzoli G. Valvular heart disease and the use of dopamine agonists for Parkinson's disease. N Engl J Med. 2007 Jan;356(1):39-46.

41 US Food and Drug Administration [Internet]. FDA public health advisory: pergolide [cited 2018 Nov 19]. Available from: http:// www.fda.gov/Drugs/DrugSafety/PublicHealthAdvisories/ucm051192.htm.

42 Votava Z, Lamplova I. Antiserotonin activity of some ergolemyn and isoergolemyn derivatives in comparison with LSD and the influence of monoamine inhibition of this antiserotonin effects. In: Rothlin E, editor. Neuropsychopharmacology. Volume II. Amsterdam: Elsevier; 1961. pp. 68-73.

43 Gräf KJ, Neumann F, Horowski R. Effect of the ergot derivative lisuride hydrogen maleate on serum prolactin concentrations in female rats. Endocrinology. 1976 Mar;98(3):598-605.
44 De Cecco L, Foglia G, Ragni N, Rossato P, Venturini PL. The effect of lisuride hydrogen maleate in the hyperprolactinaemia-amenorrhoea syndrome: clinical and hormonal responses. Clin Endocrinol (Oxf). 1978 Dec; 9(6):491-8.

45 De Cecco L, Venturini PL, Ragni N, Rossato P, Maganza C, Gaggero G, et al. Effect of lisuride on inhibition of lactation and serum prolactin. Br J Obstet Gynaecol. 1979 Nov; 86(11):905-8

46 Delitala G, Wass JA, Stubbs WA, Jones A, Williams S, Besser GM. The effect of lisuride hydrogen maleate, an ergot derivative on anterior pituitary hormone secretion in man. Clin Endocrinol (Oxf). 1979 Jul;11(1):1-9.

47 Venetikou MS, Burrin JM, Woods CA, Yeo $\mathrm{TH}$, Brownell J, Adams EF. Effects of two novel dopaminergic drugs, CV 205-502 and CQP 201-403, on prolactin and growth hormone secretion by human pituitary tumours in vitro. Acta Endocrinol (Copenh). 1987 Oct; 116(2):287-92.

48 Duranteau L, Chanson P, Lavoinne A, Horlait S, Lubetzki J, Kuhn JM. Effect of the new dopaminergic agonist CV 205-502 on plasma prolactin levels and tumour size in bromocriptine-resistant prolactinomas. Clin Endocrinol (Oxf). 1991 Jan;34(1):25-9.

49 van der Lely AJ, Brownell J, Lamberts SW The efficacy and tolerability of CV 205-502 (a nonergot dopaminergic drug) in macroprolactinoma patients and in prolactinoma patients intolerant to bromocriptine. J Clin Endocrinol Metab. 1991 May;72(5):1136-41.

50 Brue T, Pellegrini I, Gunz G, Morange I, Dewailly $\mathrm{D}$, Brownell J, et al. Effects of the dopamine agonist CV 205-502 in human prolactinomas resistant to bromocriptine. J Clin Endocrinol Metab. 1992 Mar;74(3):577-84.

51 Merola B, Sarnacchiaro F, Colao A, Di Somma C, Di Sarno A, Ferone D, et al. Positive response to compound CV 205-502 in hyperprolactinemic patients resistant to or intolerant of bromocriptine. Gynecol Endocrinol. 1994 Sep;8(3):175-81.

52 Eguchi K, Kawamoto K, Uozumi T, Ito A, Arita K, Kurisu K. Effect of cabergoline, a dopamine agonist, on estrogen-induced rat pituitary tumors: in vitro culture studies. Endocr J. 1995 Jun;42(3):413-20.

53 Eguchi K, Kawamoto K, Uozumi T, Ito A, Arita $\mathrm{K}$, Kurisu K. In vivo effect of cabergoline, a dopamine agonist, on estrogen-induced rat pituitary tumors. Endocr J. 1995 Apr;42(2): 153-61.

54 Pontiroli AE, Viberti GC, Mangili R, Cammelli L, Dubini A. Selective and extremely long inhibition of prolactin release in man by 1-ethyl-3-(3'-dimethylaminopropyl)-3- $\left(6^{\prime}\right.$ allylergoline- $8^{\prime}$-beta- carbonyl)-urea-diphosphate (FCE 21336). Br J Clin Pharmacol. 1987 Apr;23(4):433-8.
55 Andreotti AC, Pianezzola E, Persiani S, Pacciarini MA, Strolin Benedetti M, Pontiroli AE. Pharmacokinetics, pharmacodynamics, and tolerability of cabergoline, a prolactin-lowering drug, after administration of increasing oral doses $(0.5,1.0$, and 1.5 milligrams) in healthy male volunteers. J Clin Endocrinol Metab. 1995 Mar;80(3):841-5.

56 Melis GB, Gambacciani M, Paoletti AM, Beneventi F, Mais V, Baroldi P, et al. Doserelated prolactin inhibitory effect of the new long-acting dopamine receptor agonist cabergoline in normal cycling, puerperal, and hyperprolactinemic women. J Clin Endocrinol Metab. 1987 Sep;65(3):541-5.

57 Mattei AM, Ferrari C, Baroldi P, Cavioni V, Paracchi A, Galparoli C, et al. Prolactin-lowering effect of acute and once weekly repetitive oral administration of cabergoline at two dose levels in hyperprolactinemic patients. J Clin Endocrinol Metab. 1988 Jan;66(1): 193-8.

58 Webster J, Piscitelli G, Polli A, Ferrari CI, Ismail I, Scanlon MF; Cabergoline Comparative Study Group. A comparison of cabergoline and bromocriptine in the treatment of hyperprolactinemic amenorrhea. N Engl J Med. 1994 Oct;331(14):904-9.

59 Colao A, Di Sarno A, Landi ML, Cirillo S, Sarnacchiaro F, Facciolli G, et al. Long-term and low-dose treatment with cabergoline induces macroprolactinoma shrinkage. J Clin Endocrinol Metab. 1997 Nov;82(11):3574-9.

60 Colao A, Di Sarno A, Landi ML, Scavuzzo F, Cappabianca P, Pivonello R, et al. Macroprolactinoma shrinkage during cabergoline treatment is greater in naive patients than in patients pretreated with other dopamine agonists: a prospective study in 110 patients. J Clin Endocrinol Metab. 2000 Jun;85(6):224752.

61 Biller BM, Colao A, Petersenn S, Bonert VS, Boscaro M. Prolactinomas, Cushing's disease and acromegaly: debating the role of medical therapy for secretory pituitary adenomas. BMC Endocr Disord. 2010 May;10(17):10.

62 Molitch ME. Pharmacologic resistance in prolactinoma patients. Pituitary. 2005;8(1): 43-52.

63 Wang F, Gao H, Li C, Bai J, Lu R, Cao L, et al. Low levels of PRB3 mRNA are associated with dopamine-agonist resistance and tumor recurrence in prolactinomas. J Neurooncol. 2014 Jan;116(1):83-8.

64 Gao H, Wang F, Lan X, Li C, Feng J, Bai J, et al. Lower PRDM2 expression is associated with dopamine-agonist resistance and tumor recurrence in prolactinomas. BMC Cancer. 2015 Apr;15(1):272-81.

65 Li Z, Liu Q, Li C, Zong X, Bai J, Wu Y, et al. The role of TGF- $\beta /$ Smad signaling in dopamine agonist-resistant prolactinomas. $\mathrm{Mol}$ Cell Endocrinol. 2015 Feb;402:64-71.

66 Marques P, Korbonits M. Genetic Aspects of Pituitary Adenomas. Endocrinol Metab Clin North Am. 2017 Jun;46(2):335-74. 
67 Thakker RV, Newey PJ, Walls GV, Bilezikian J, Dralle H, Ebeling PR, et al.; Endocrine Society. Clinical practice guidelines for multiple endocrine neoplasia type 1 (MEN1). J Clin Endocrinol Metab. 2012 Sep;97(9):2990-3011.

68 Vroonen L, Jaffrain-Rea ML, Petrossians P, Tamagno G, Chanson P, Vilar L, et al. Prolactinomas resistant to standard doses of cabergoline: a multicenter study of 92 patients. Eur J Endocrinol. 2012 Nov;167(5):651-62.
69 Colao A, Sarno AD, Cappabianca P, Briganti F, Pivonello R, Somma CD, et al. Gender differences in the prevalence, clinical features and response to cabergoline in hyperprolactinemia. Eur J Endocrinol. 2003 Mar; 148(3):325-31.

70 Delgrange E, Daems T, Verhelst J, Abs R, Maiter D. Characterization of resistance to the prolactin-lowering effects of cabergoline in macroprolactinomas: a study in 122 patients. Eur J Endocrinol. 2009 May;160(5):747-52.
71 Salenave S, Ancelle D, Bahougne T, Raverot G, Kamenický P, Bouligand J, et al. Macroprolactinomas in children and adolescents: factors associated with the response to treatment in 77 patients. J Clin Endocrinol Metab. 2015 Mar;100(3):1177-86

72 Faje A, Chunharojrith P, Nency J, Biller BM, Swearingen B, Klibanski A. Dopamine Agonists Can Reduce Cystic Prolactinomas. J Clin Endocrinol Metab. 2016 Oct;101(10):3709-15. 